\title{
Pendampingan Keluarga Dalam Memberikan Dukungan Terhadap Keberhasilan Pemberian ASI Ekslusif
}

\author{
Sri Sumarni ${ }^{1}$, Nelyta Oktavianisya ${ }^{2}$ \\ Program Studi Ilmu Keperawatan, Fakultas Ilmu Kesehatan \\ e-mail: sri.sumarni73@yahoo.co.id,nelyta@wiraraja.ac.id
}

\begin{abstract}
Abstrak
Pemberian ASI (Air Susu Ibu) merupakan nutrisi yang dibutuhkan untuk pertumbuhan dan perkembangan bayi. Dukungan orang sekitar atau orang terdekat, menjadi penentu keberhasilan menyusui. Apabila dukungan untuk menyusui yang diperoleh ibu optimal maka ibu akan bertahan dalam menyusui. Masalah penelitian adalah rendahnya pemberian ASI Eksklusif di Desa Lebeng Timur Kecamatan Pasongsongan sebesar 4,5\% dari target 90\%. Solusi permasalahan tersebut adalah dengan pemberian pemahaman tentang dukungan keluarga dalam kesuksesan pemberian ASI Eksklusif. Jenis kegiatan ini berupa sosialisasi dan pendampingan keluarga dalam memberikan dukungan pada keberhasilan pemberian ASI Eksklusif. Tempat atau lokasi kegiatan PKM dilaksanakan di Desa Lebeng Timur Kecamatan Pasongsongan, yang dilaksanakan pada bulan Oktober-Desember 2017, dengan kelompok sasaran PKM adalah lingkungan sekitar Warga. Hasil kegiatan penyuluhan dan pendampingan pada masyarakat berdampak baik khusunya bagi masyarakat atau keluarga dengan ibu menyusui, dimana keluarga dapat mengetahui cara memberi dukungan dalam keberhasilan pemberian ASI Eksklusif.
\end{abstract}

\section{Kata Kunci: ASI Eksklusif; Dukungan Keluarga}

\begin{abstract}
Breastfeeding is a nutrient needed for growth and development of babies. Support of the people around or the closest person, determines the success of breastfeeding. If the support for breastfeeding obtained by the mother is optimal, the mother will survive breastfeeding. The research problem is the low level of exclusive breastfeeding in Lebeng Timur Village, Pasongsongan District, at 4.5\% of the target of 90\%. The solution to this problem is to provide an understanding of family support in the success of exclusive breastfeeding. This type of activity is in the form of familiarization and family assistance in providing support for the success of exclusive breastfeeding. The place or location of PKM activities is held in Lebeng Timur Village, Pasongsongan District, which is held in October-December 2017, with the PKM target group being the environment around the Citizens. The results of counseling and mentoring activities for the community have a good impact especially for the community or families with nursing mothers, where families can find out how to provide support in the success of exclusive breastfeeding
\end{abstract}

Keywords: Exclusive Breast Milk; Family Support 


\section{PENDAHULUAN}

Menyusui merupakan proses fisiologis, settiap anak mempunyai haak dalam memperoleh nutrisi yang berekualitas sejak awal kehidupan. Pemberian ASI (Air Susu Ibu) merupakan nutrisi yang baik dalam menunjang kesehatan, perkembangan dan pertumbuhan bayi. Salah satu cara dalam meningkatkan dan memperbaiki status gizi bayi adalah dengan memberikan ASI secara eksklusif. World Health Organization (WHO) menyarankan pemberian ASI eksklusif sekurang kurangnya selama enam bulan pertama sejak dilahirkan dan dilanjutkan dengan memberikan MP-ASI sampai usia dua tahun. Rekomendasi serupa juga didukung oleh AAP (American Academy of Pediatrics), Academy of Breasfeeding Medicine. Hal ini didukung pula oleh Ikatan Dokter Anak Indonesia (IDAI) ${ }^{1}$

ASI eksklusif adalah air susu ibu diberikan selama enam bulan kepada bayi, tanpa tambahan cairan lain seperti susu formula, bahkan air putih serta tanpa tambahan makanan padat (pisang, bubur susu, biskuit, bubur nasi dan nasi tim) ${ }^{2}$. WHOUNICEF tahun 2002 pada Global Strategy for Infant and Young Child Feeding mengaplikasikan cara memberikan makan bayi yang benar yaitu memberrikan ASI eksklusif sejak pertama dilahirkan sampai bayi berumur enam bulan dan dilanjutkan sampai umur dua tahun dan pemberian Makanan Pendamping ASI (MP-ASI) setelah bayi berrumur enam bulan ${ }^{3}$.

Pemberian air ASI secara eksklusif kepada bayi di Negara Indonesia berlandaskan Kemenkes RI No. 450/MENKES/SK/IV/2004 tanggal 7 April 2004 yang merujuk juga pada Resolusi World Health Assembly (WHA), untuk mencapai kesehatan, pertumbuhan dan perkembangan optimal, ASI Eksklusif harus diberikan pada bayi selama enam bulan sejak pertama dilahirkan (Prasetyono, 2009). Pemberian ASI sangat penting bagi tumbuh kembang baik fisik dan mental serta daya tanggap atau kecerdasan bayi. ASI eksklusif melindungi bayi dari berbagai penyakit yang umum yaitu diare dan infeksi ${ }^{4}$. Kandungan ASI selain nutrisi juga terdapat unsur kekebalan dan unsur hormon, faktor pertumbuhan, anti alergi, serta anti inflamasi. Kandungan nutrisi ASI yaitu hampir mengandung unsur zat makanan sampai 200. Unsur ini mencakup hidrat arang, lemak, protein, vitamin dan mineral dalam jumlah yang proporsional.

Bayi yang tidak mendapatkan ASI, kemungkinan terkena diare 14,2 kali lebih sering jika dibandingkan bayi yang diberikan ASI eksklusif. ASI juga bermanfaat karena mengandung kolostrum sebagai zat kekebalan ${ }^{10}$.Penyebab berkurangnya jumlah pemberian ASI eksklusif yaitu usia muda saat melahirkan, kurang pendidikan, melahirkan pertama kali, faktor pekerjaan, pengetahuan ibu yang kurang tentang manfaat memberikan ASI eksklusif, pemasaran susu formula dan budaya pemberian MPASI terlalu dini di masyarakat ${ }^{6}$. Dukungan orang sekitar atau orang terdekat, mempunyai peranan penitng dalam menentukan sukses atau tidak suksenyanya ibu menyusui. Jika dukungan yang didapatkan ibu optimal untuk menyusui maka kemampuan untuk dapat bertahan dalam menyusui semakin besar. Dukungan yang paling penting dari suami maupun keluarga ${ }^{5}$.

Dukungan keluarga adalah faktor luar yang mempunyai pengaruh besar terhadap keberhasilan ASI eksklusif. Adanya dukungan keluarga terutama suami akan meningkatkan rasa percaya diri dan memberikan motivasi tersendiri bagi ibu dalam menyusui ${ }^{7}$. Suririnah menyatakan bahwa motivasi ibu sangat menentukan dalam pemberian ASI eksklusif selama enam bulan. Dorongan dari pemerintah, petugas kesehatan dan keluarga adalah penentu adanya motivasi ibu untuk menyusui ${ }^{11}$. 
Friedman mengatakan bahwa dukungan keluarga ada 4 bentuk, yaitu dukungan informasional, dukungan penghargaan, dukungan instrumental, dan dukungan emosional ${ }^{13}$. Ibu menyusui membutuhkan dukungan dari saat memulai dan juga untuk melanjutkan menyusui. Ibu menyusui membutuhkan dukungan dari keluarga maupun lingkungannya serta perawatan kesehatan dalam pemberian ASI hingga dua tahun ${ }^{4}$. Keluarga terutama suami mempunyai peranan penting dalam menentukan keberhasilan ataupun kegagalan menyusui, karena suami menentukan kelancaran pengetahuan ASI (let down refelex) yang dipengaruhi oleh keadaan emosi dan perasaan ibu ${ }^{7}$.

KTT dalam Roesli, merekomendasikan pentingnya dukungan keluarga dalam memberikan ASI ${ }^{7}$. Semua keluarga seharusnya mengetahui arti pentingnya dukungan bagi ibu untuk hanya memeberikan ASI pada 4 sampai 6 bulan pertama kehidupan bayi dan juga mencukupi kebutuhan makanan pada bayi. Dukungan suami maupun keluarga sangat besar pengaruhnya, seorang ibu yang kurang mendapatkan dukungan oleh suami, ibu, adik atau bahkan ditakut-takuti, dipengaruhi untuk beralih ke susu formula ${ }^{5}$.

Berdasarkan data Dinas Kesehatan Kabupaten Sumenep, cakupan ASI Eksklusif di Kabupaten Sumenep pada tahun 2012 masih rendah yaitu sebesar 8, 9\%. Cakupan ASI Eksklusif yang tergolong rendah di Kabupaten Sumenep adalah di UPT Puskesmas Pasongsongan yaitu ada 23 bayi (7, 8\%) yang diberi ASI Eksklusif dengan jumlah bayi sebesar 292 bayi. Menurut Dinkes Kabupaten Sumenep pencapaian cakupan ASI Eksklusif tahun 2010 mencapai 25,3\%, tahun 2011 mencapai 11,9\%, tahun 2012 mencapai 8,9\%. Sedangkan cakupan ASI Eksklusif di wilayah kerja UPT Puskesmas Pasongsongan tahun 2010 mencapai 27,5\%, tahun 2011 mencapai 2,4\% dan tahun 2012 mencapai 7,8\%. Berdasarkan data pemberian ASI Eksklusif di
Puskesmas Pasongsongan tahun 2012 diketahui dari 10 desa yang ada, Lebeng Timur (4,5\%) adalah desa yang terendah dalam pemberian ASI Eksklusif. Hal ini menunjukkan bahwa desa Lebeng Timur Kec. Pasongsongan masih jauh di bawah target SPM (Standar Pelayanan Minimal) Kabupaten Sumenep.

Cakupan pemberian ASI Eksklusif di Desa Lebeng Timur terendah yaitu hanya mencapai 4, 5\%. Sehingga masalah penelitian adalah rendahnya pemberian ASI Eksklusif di Desa Lebeng Timur Kec. Pasongsongan sebesar 4, 5\% dari target 90\%. Hal ini didukung dengan adanya hambatan pada ibu dalam menyusui memberikan ASI eksklusif yaitu rendahnya dukungan keluarga dalam pemberian ASI. Terutama dukungan suami, karena suami sebagai pengambil keputusan dalam keluarga.

\section{SUMBER INSPIRASI}

\section{Peran Keluarga dalam Pemberian ASI Ekslusif}

Menurut Friedman, tipe-tipe keluarga antara lain (1) keluarga inti atau konjugal yaitu keluarga yang menikah, sebagai orang tua ayah pemberi nafkah, keluarga inti terdiri dari suami, isteri dan anak mereka, baik anak kandung maupun anak adopsi, (2) keluarga orientasi yaitu keluarga inti dan orang yang mempunyai hubungan darah seperti kakek/nenek, bibi, paman dan sepupu ${ }^{12}$. Friedman dalam Sudiharto, mengatakan bahwa fungsi dasar keluarga yaitu fungsi efektif ${ }^{14}$. Fungsi Efektif adalah fungsi internal keluarga untuk pemenuhan kebutuhan psikososial, saling mengasuh dan mengasihi serta saling menerima dan mendukung. Dukungan keluarga, bagian integral dari dukungan sosial. Dukungan keluarga, memiliki dampak positif yaitu dapat meninggikan proses penyusuaian diri pada kejadian yang terrjadi dalam kehidupan seseorang ${ }^{13}$.

Baik keluarga inti maupun keluarga besar memiliki fungsi sebagai sistem pendukung untuk anggota keluarganya. Caplan dalam Friedman, menyatakan bahwa keluarga berfungsi memberikan 
dukungan yaitu dukungan informasional, dukungan penilaian, dukungan isntrumental dan dukungan emosional $^{12}$. Dukungan informasional adalah keluarga memiliki fungsi sebagai sebuah keluarga disseminator/ penyebar informasi yang ada dalam kehidupan. Keluarga mencari informasi terkait dengan menyusui dan melakukan konsultasi dengan tenaga kesehatan, serta menemukan informasi dari media maupun sumber lainnya.

Dukungan penilaian merrupakan dukungan keluarga yang bertindak sebagai pembimbing dalam, memecahkan masalah dan sebagai sumber validator identitas anggota keluarga. Dukungan instrumental yaitu salah satu dukungan dkeluarga dengan fungsi seebagai sumber pertolongan praktis dan konkrit untuk menyelesaikan masalah. Serta dukungan emosional merupakan dukungan dimana keluarga sebagai tempat pemulihan teraman dan mendamaikan untuk beristirahat dan membantu secara psikologis dalam proses membuat tabik emosi serta mengendalikan diri. Salah satu bentuk melalui pemberian motivasi dan fasilitator serta mendengarkan semua keluh kesah anggota keluarga atau ibu mengenai masalahnya (Caplan dalam Friedman) ${ }^{12}$.

Menurut Watson dalam Friedman, mengungkapkan bahwa bentuk dukungan keluarga yaitu bisa berupa pemberian bantuan dalam bentuk materi seperti memberikan pinjaman uang, bantuan fisik berupa alat-alat atau lainnya yang mendukung dan membantu menyelesaikan masalah ${ }^{12}$. Dalam mengatasi ketegangan kehadiran keluarga sangat penting untuk mendorong ibu dalam meningkatkan kepercayaan diri dan menstabilkan emosinya, juga bisa memberikan motivasi terhadap ibu yang menyusui secara optimal.

Menurut Sudiharto menjelaskan bahwa dukungan keluarga memiliki hubungan dengan sukses tidaknya pemberian ASI Eksklusif pada bayi ${ }^{14}$.. Dukungan keluarga dapat menumbuhkaan motivasi ibu dalam memberikan ASI saja kepada bayi sampai usia enam bulan, ibu mendapatkan dukungan psikologis dan nutrisi yang seimbang. Menurut Roesli, suami dan keluarga dapat berperan aktif pada prosess pemberian ASI dengan dukungan emosional atau bantuan praktis lainnya ${ }^{9}$.

\section{Tujuh Langkah Keberhasilan ASI Eksklusif}

Langkah-langkah keberhasilan ASI Eksklusif penting terutama bagi ibu karir. Menyusui akan berdampak pada seluruh keluarga. Idealnya suami, kakak, nenek, dan kakek ikut terlibat dalam langkahlangkah ini, karena dukungan dari orang-orang teersebut sangat penting. Menurut Utami Roesli langkah yang paling penting untuk persiapan keberhasilan menyusui secara Eksklusif adalah berrikut ini :1). Mempersiapkan payudara bila diperlukan, 2). Menambah pengetahuan tentang ASI dan tata laksana menyusui, 3). Menciptakan dukungan keluarga, teman, dan sebagainya, 4). Memilih tempat melahirkan yang pro ASI Eksklusif, 5). Memilih tenaga kesehatan yang pro pemberian ASI secara Eksklusif, 6). Mencari ahli persoalan menyusui seperti Klinik laktasi, 7). Menciptakan sikap yang positif dan pro tentang ASI dan menyusui ${ }^{8}$.

\section{METODE KEGIATAN}

Kegiatan PKM dilaksanakan di Balai Desa Lebeng Timur Kec. Pasongsongan. Kegiatan PKM dilaksanakan selama 6 bulan, dari bulan Agustus 2017 sampai dengan Januari 2018. Kelompok Sasaran adalah lingkungan sekitar Warga Desa Lebeng Timur Kec. Pasongsongan khususnya warga yang memiliki keluarga yang sedang hamil atau menyusui bayi 0-6 bulan.

\section{Metode Pelaksanaan Kegiatan}

Sosialisasi dilakukan setelah adanya kepastian dari LPPM Universitas Wiraraja Sumenep tentang 
kegiatan ini dan dimaksudkan untuk melihat kesiapan lokasi dan sasaran atau mitra sebagai potret awal daerah kegiatan.Materi penyuluhan di buat dalam dua bentuk yang pertama yaitu dalam bentuk leaflet dan yang kedua dalam bentuk powerpoint.Sarana prasarana yang pelu dipersiapkan pada kegiatan ini meliputi; (1) perlengkapan dan bahan Penyuluhan; (2) Tata ruang/ lay out tempat penyuluhan.

Pelaksanaan Penyuluhan. Tahapan ini peserta penyuluhan akan diberikan pengetahuan tentang pentingnya dukungan keluarga terhadapa keberhasilan ibu menyusui dalam pemberian ASI Ekslusif,. Peserta yang terlibat pada kegiatan ini adalah masyarakat sekitar Desa Lebeng Timur.

Tahap Pelaporan Akhir. Laporan akhir merupakan laporan dari seluruh rangkaian kegiatan sebagai wujud pertanggungjawaban secara inistratif dari tim pelaksana kepada LPPM Universitas Wiraraja Sumenep.Langkah-langkah Kegiatan penyuluhan didpaarkan dalam Tabel 1.

\section{KARYA UTAMA}

Adapun indikator pencapaian target dan luaran PKM sosisalisasi pentingnya dukungan keluaraga terhadap keberhasilan pemberian ASI eksklusif di Desa Lebeng Timur Kec. Pasongsongan Kabupaten Sumenep adalah peningkatkan pengetahuan dan perilaku keluarga dan kader kesehatan dalam melakukan memberikan dukungan terhadap keberhasilan pemeberian ASI Eksklusif dapat dilihat pada Gambar 1 dan 2. Penyampaian dengan menggunakan leaflet dan power point (Gambar 3 dan Gambar 4). Proses pemahaman dan penyampaian informasi yang akurat pada keluarga dan masyarakat dalam mencari solusi dalam memberikan dukungan kepada ibu yang memiliki bayi 0-6 bulan .Meningkatkan kesadaran mandiri ibu yang memiliki bayi 0-6 bulan ditunjukkan pada Gambar 5 .

\section{ULASAN KARYA}

Hasil kegiatan penyuluhan di Desa Lebeng Timur diikuti oleh seluruh masyarakat yang memiliki bayi sebanyak 40 orang dimana berdasarkan kegiatan yang telah dilakukan dalam bentuk ceramah terdapat beberapa hasil evaluasi kegiatan diantaranya: 1). Evaluasi Struktur. Kepala Desa Lebeng Timur Kec. Pasongsongan dapat bekerja sama dengan baik dan kooperatif dibuktikan dengan dalam persiapan kegiatan dengan ikut serta menyiapkan atau membuat setting tempat penyuluhan. Kepala Desa Lebeng Timur Kec.Pasongsongan tampak antusias menerima kunjungan dari tim PKM yaitu dosen Prodi S1 Keperawatan Universitas Wiraraja Sumenep. 2). Evaluasi Proses. Timur Kec. Pasongsongan yang mayoritas diikuti oleh masyarakat di lingkungan Desa Lebeng Timur Kec. Pasongsongan, dimana peserta terlihat aktif dalam berdiskusi serta mengikuti pelayanan kesehatan dengan konsultasi masalah kesehatan bagi dirinya dan bayinya.Peserta kegiatan dapat mengerti pentingnya ASI ekslusif serta keberhasilan pemberian didukung oleh peran keluarga dibuktikan dengan para peserta dapat menjelaskan pentingnya Asi ekslusif dan pentingnya peran keluarga.3). Evaluasi Hasil. Peserta kegiatan dapat mengerti dan memahami tentang pentingnya dukungan keluarga dalam keberhasilan pemberian Asi ekslusif. Peserta penyuluhan dapat mendemonstrasikan cara membuat rileks ibu menyusui sehingga mendukung lancarnya ASI, 4). Keberlanjutan. Bagi Masyarakat dilingkungan Desa Lebeng Timur Kec.Pasongsongan perlunya meningkatkan tingkat pengetahuan masyarakat sehingga dapat meningkatkan pengetahuan masyarakat pada umumnya, dan dapat memberikan informasi khusus tentang Pentingnya dukungan keluarga dalam keberhasiilan pemeberian ASI ekslusif, sehingga dapat memberikan manfaat kesehatan masyarakat secara konprehensif. 
Tabel 1. Kegiatan Penyuluhan Pentingnya Dukungan Keluarga terhadap Keberhasilan Ibu Menyusui dalam Pemberian ASI Ekslusif

\begin{tabular}{|c|c|c|c|}
\hline No & Kegiatan Penyuluh & Respon Peserta & Waktu \\
\hline 1 & $\begin{array}{l}\text { Pendahuluan } \\
\text { a. Memberi salam dan Berdoa } \\
\text { b. Memberi pertanyaan apersepsi } \\
\text { c. Mengkomunikasikan pokok bahasan } \\
\text { d. Menjelaskan tujuan }\end{array}$ & $\begin{array}{l}\text { a. Menjawab salam } \\
\text { b. Memberi salam } \\
\text { c. Menyimak } \\
\text { d. Menyimak }\end{array}$ & $10 \mathrm{mnt}$ \\
\hline 2 & $\begin{array}{l}\text { Kegiatan Inti } \\
\text { a. Memberikan penjelasan tentang pentingnya dukungan keluarga dalam } \\
\text { pemberian ASI ekslusif } \\
\text { b. Memberikan kesempatan warga untuk bertanya } \\
\text { c. Menjawab pertanyaan warga }\end{array}$ & $\begin{array}{ll}\text { a. } & \text { Menyimak } \\
\text { b. Bertanya } \\
\text { c. }\end{array}$ & $25 \mathrm{mnt}$ \\
\hline 3 & $\begin{array}{l}\text { Penutup } \\
\text { a. Menyimpulkan materi penyuluhan bersama keluarga } \\
\text { b. Memberikan evaluasi secara lisan } \\
\text { c. Memberikan salam penutup }\end{array}$ & $\begin{array}{l}\text { a. Memperhatikan } \\
\text { b. menjawab }\end{array}$ & $5 \mathrm{mnt}$ \\
\hline
\end{tabular}

Tabel 2. Rencana target capaian luaran

\begin{tabular}{ll}
\hline \hline Jenis Luaran & Indikator Capaian \\
\hline Luaran Wajib & \\
\hline Publikasi ilmiah pada jurnal ber ISBN/ Prosiding jurnal Nasional & Draf \\
\hline Publikasi pada media massa (cetak/online/repositori PT) & Draft \\
\hline $\begin{array}{l}\text { Peningkatan daya saing (peningkatan kualitas,kuantitas, serta nilai } \\
\text { tambah dan sumber daya lainnya) }\end{array}$ & Belum \\
\hline $\begin{array}{l}\text { Peningkatan penerapan iptek di masyarakat (mekanisme,IT dan } \\
\text { manajemen) }\end{array}$ & Belum \\
\hline Perbaikan tata nilai masyarakat & Draf \\
\hline Luaran Tambahan & \\
\hline Publikasi di jurnal internasional & Belum \\
\hline Jasa & Belum \\
\hline Inovasi baru TTG & Belum \\
\hline HAKI & Belum \\
\hline Buku ber ISBN & Belum \\
\hline
\end{tabular}

Dokumentasi Kegiatan Pengabdian Kepada Masyarakat

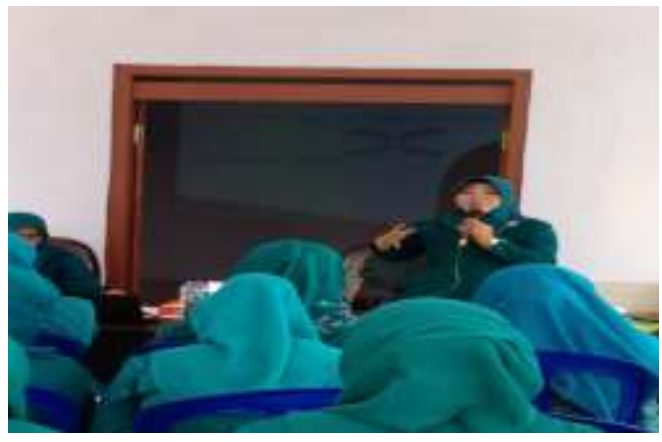

Gambar 1. Pemberian Materi Tentang pentingnya ASI Eksklusif

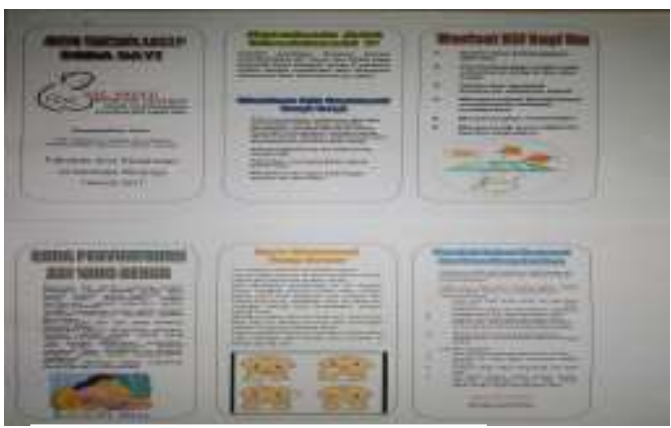

Gambar 3. Leaflet ASI Eksklusif

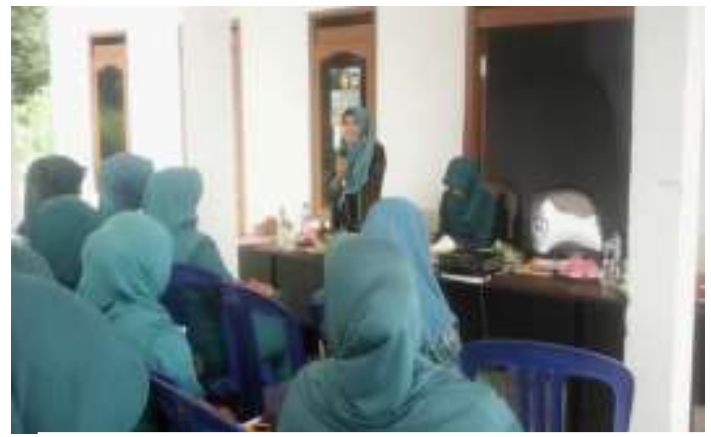

Gambar 2. Pemberian Materi Faktor Pendukung Keberhasilan ASI Eksklusif

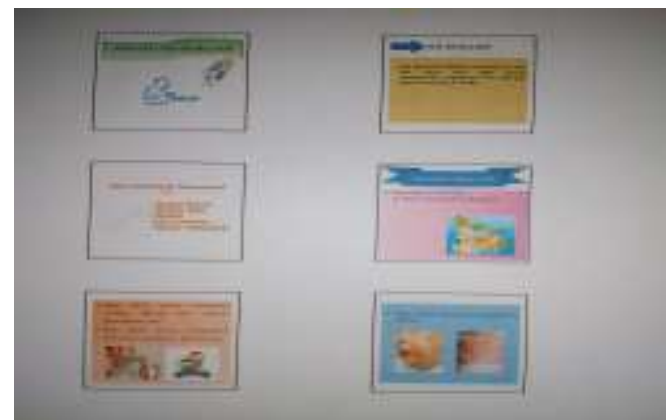

Gambar 4. Power Point ASI Eksklusif ASI Eksklusif 


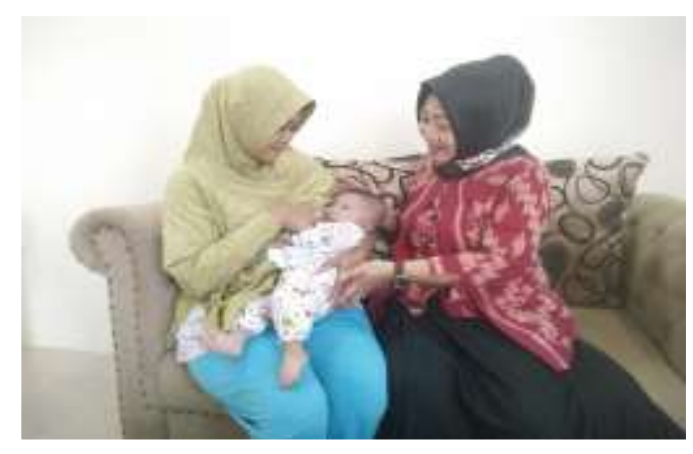

Gambar 5. Pemberian ASI Esklusif

Pelaksanaan penyuluhan kesehatan terlihat aktif diikuti masyarakat dilingkungan Desa Lebeng

Faktor pendorong yang menguatkan yakni peran serta mitra dalam kegiatan Pengabdian Kepada Masyarakat cukup aktif di buktikan sejak awal persiapan kegiatan mulai dari penyuluhan. Sedangkan faktor penghambat adalah sebagian besar masyarakat mempunyai latar belakang pendidikan Sekolah Dasar, sehingga membutuhkan waktu yang lama dan komunikasi yang baik dan terperinci untuk meninggaktan pengetahuan keluarga dalam memberikan dukungan terhadap keberhasilan pemberian ASI eksklusif, serta sebagian besar keluarga pasien dari kalangan pendapatan ekonomi ke bawah, sehingga banyaknya keluarga kurang dalam mengakses informasi mengenai ASi eksklusif.

Berdasarkan hasil kegiatan penyuluhan dan pendampingan kepada warga masyarakat di Desa Lebeng Timur Kec. Pasongsongan berdampak baik khusunya bagi masyarakat atau keluarga dengan ibu menyusui, dimana keluarga dapat mengetahui dan meneerapkan cara memberi dukungan untuk keberhasilan pemberian ASI Eksklusi.

\section{KESIMPULAN}

Pelaksanaan program kegiatan Pengabdian Kepada Masyarakat yang dilakukan di Desa Lebeng Timur Kec. Pasongsongan berupa sosialisasi dan pendampingan keluarga dalam memberikan dukungan pada keberhasilan pemberian ASI
Eksklusif pada dasarnya berusaha untuk memberikan tambahan wawasan bagi masyarakat akan manfaat dari pentinngnya ASI Eksklusif. Karena kemampuan tingkat pengetahuan masyarakat akan sendirinya mampu memberikan kontribusi positif terutama bagi peningkatan hidup masyarakat sendiri, terutama dalam upaya meningkatkan status kesehatan bayi dan balita. Hasil yang diperoleh sesuai dengan target yaitu keluarga bisa memberikan dukungan kepada ibu menyusui dalam mencapai keberhasilan pemberian ASI Eksklusif.

\section{DAMPAK DAN MANFAAT KEGIATAN}

Melalui Program Pengabdian Kepada Masyarakat di Desa Lebeng Timur Kec. Pasongsongan Kabupaten Sumenep, maka luaran yang diharapkan adalah sebagai berikut:

1. Terwujudnya pengetahuan masyarakat tentang pentingnya dukungan keluarga dalam pemberian ASI Ekslusif di lingkungan Desa Lebeng Timur .

2. Terciptanya lingkungan sehat di Desa Lebeng Timur Kec. Pasongsongan.

3. Aktifnya peran tokoh masyarakat dan anggota keluarga dalam keikutsertaan peningkatan kesehatan masyarakat di lingkungannya khususnya tentang Pemberian ASI Ekslusif. 


\section{DAFTAR PUSTAKA}

1. Suradi R, Hegar B, Partiwi I Gusti A, Marzuki A, Ananto."Indonesia Menyusui". Badan Penerbit IDAI.2010.

2. Kristiyansari, Weni. "ASI, Menyusui, dan Sadari”. Yogyakarta : Nuha Medika.2009.

3. Kementrian Kesehatan RI.Pedoman Pekan ASI Sedunia (PAS). Jakarta: Kementrian Kesehatan RI.2010.

4. Proverawati."Buku Ajar Kesehatan Resproduksi Untuk Kebidanan”. Yogyakarta: Nuha Medika.2010

5. Proverawati A.,Rahmawati, E."Kapita Selekta ASI dan Menyusui". Yogyakarta : Nuha Media.2010.

6. Soetjiningsih."ASI: Petunjuk untuk tenaga kesehatan”. Jakarta:EGC.1997.

7. Roesli, Utami."Mengenal ASI Eksklusif". Jakarta: PT Elex Komputindo.2004.
8. Roesli, Utami."Inisiasi Menyusu Dini plus ASI Eksklusif “. Jakarta: Pustaka.2005

9. Roesli, Utami. "Inisiasi Menyusui Dini". Jakarta. Trubus Agriwidya.2008

10. Purwanti."Konsep Penerapan ASI Eksklusif". Bandung : Cendekia.2004.

11. Suririnah."Buku Pintar Merawat Bayi Umur 0-12 Bulan”. Jakarta : PT Gramedia Pustaka Utama.2009.

12. Friedman."Keperawatan Keluarga". Jakarta : EGC.1998.

13. Friedman. "Buku ajar keperawatan keluarga: riset, teori dan praktik". Jakarta : EGC.2010

14. Sudiharto."Asuhan Keperawatan Keluarga dengan Pendekatan Keperawatan Transkultural”, Jakarta: EGC.2007. 